\title{
An Integrated Sustainable Vegetable Production System
}

\author{
Sharad C. Phatak \\ Department of Horticulture, Coastal Plain Experiment Station, University of Georgia, Tifton, GA 31793
}

Sustainable agriculture means many things to many people. To environmentalists the term may mean protection and/or renewal of agricultural-natural resources. To growers and consumers of organic food products, the term means producing foodstuffs without chemical inputs. Other terms-regenerative, low-input, alternative, renewable, organic-have been used synonymously for sustainable. This illustrates existing confusion. Whether conventional or sustainable, profit remains an integral part of the picture for agricultural industry to survive.

Opinions vary greatly in defining what sustainable agriculture is, as each division of agriculture has its own definition. It has been called organic farming, which is a system of production that largely avoids the use of chemical fertilizers, pesticides, and plant growth regulators (U.S. Dept. Agriculture, 1980). Whenever feasible, sustainable agriculture relies upon crop rotations, crop residues, animal manures, offfarm organic wastes, mechanical cultivation, mineral-bearing rocks, and aspects of biological pest control to maintain the soil and its tillage, to supply plant nutrients, and to control insects and weeds (Oelhaf, 1978; U.S. Dept. Agriculture, 1980). MacRae et al. (1989) defined sustainable agriculture as a philosophy and system of farming based on a set of values that involve benign designs and management procedures that work with natural processes to conserve all resources, minimize waste and environmental impact, prevent problems, and promote agroecosystem resilience, self-regulation, evolution, and sustained production for the nourishment and fulfillment of all. Lowrance et al. (1984) based sustainable agriculture on an application of an ecological model, while Odum (1984) stated that agroecosystems differ from natural ecosystems in that they are partly powered by auxiliary energy sources (processed fuels, animal and human power). Such a description includes farming systems variously referred to as organic, biological, ecological, agroecological, biodynamic, regenerative, alternative, natural, and permanent (Odum, 1984).

Development of organic farming was based on the analysis of farming systems by agronomist F.H. King (1927) and the composting and humus research of Sir Albert Howard (1940). Sir Albert conducted most of his research on composting at the Institute of Plant Industries, Indore, M.P., India, located only a few miles from my father's farm. Sir Albert's ideas were regularly tested on our farm. My father farmed from early 1920 s to early 1980 s. He raised every vegetable crop that had a market. Until the early 1950s crops were produced without fertilizers or pesticides. I was an undergraduate in Madhya Bharat College of Agriculture, Gwalior (Now Jawaharlal Nehru Agricultural Univ.) during that period. I heard about various fertilizers and new chemical pesticides from my professors, most of whom had recently returned from the United States and other developed countries. These new chemical wonders had an impact on me. I talked to my father about them over the summers when I was home working on the farm with him. Slowly, he started using fertilizers and pesticides.

Soon the Green Revolution followed, which brought in new varieties of wheat, rice, and other crops that required high inputs. At first, yield increased dramatically. However, today it is difficult to grow any crop without high inputs. In 1985 when I visited India I had an opportunity to analyze and compare my father's farming practices

I thank my colleagues, D.R. Sumner, R.B. Chalfant, L.D. Chandler, J.D. Gay, and R.L. Bugg for their contributions and Jimmy Hornbuckle, Anthony Bateman, and Kate Brunson for their valuable help .This project was funded in part through the Southern Regional IPM Program of the Cooperative State Research Service, USDA Grant 89-34103-4257. from the 1920 s to the 1980 s, -60 years. For the first 30 years, from the early 1920 s to the early 1950 s, he farmed without using off-farm inputs (now referred to as organic farming, sustainable agriculture, etc.) In the next 30 years, modem agricultural techniques (now referred to as conventional agriculture or industrial agriculture) were used. Yield for the first 30 years stayed constant, and because of the low cost of production, profits were higher. The second 30 years' yields increased dramatically in the beginning. However, with total dependence on high inputs, profits dwindled. The most detrimental effect of modem agriculture was that soils became nonproductive without high off-farm inputs. This was probably due to the fact that old practices of green manuring, application of compost, crop rotations, companion cropping, relay cropping, etc. were ignored. On my return to the United States, I started a research project with the help of colleagues to incorporate strategies followed by my father during his first 30 years of farming (sustainable agriculture).

We have a long way to go. The success of strategies depends on long-term, whole-farm systems involving all aspects of crop production that will maintain soil productivity and reduce dependence on offfarm inputs. However, we made substantial progress, although our multi-disciplinary research indicated some weaknesses that need further research. Strengths and weaknesses of various strategies are presented below.

\section{Tillage}

An important objective of tillage in vegetable production is to change the soil to provide optimum conditions for plant growth (Phatak, 1987a). Conservation tillage has not been researched in vegetable production as in agronomic crops (Sumner et al., 1986b). Phatak (1987a) suggested using conservation tillage for vegetables only where it has been proved consistently successful. With the present emphasis on sustainable vegetable production to reduce off-farm inputs and for soil conservation, we need to re-evaluate and develop techniques to use conservation tillage in vegetable production.

Cover crops have become important in conservation tillage practices because they control soil erosion and help increase soil tilth (Pieters, 1927). This is especially true in Georgia where the soils are of low fertility with little organic matter. Hargrove (1986) used crimson clover (Trifolium incarnatum L.) with no-till sorghum (Sorghum bicolor Moench.) and soybeans and observed an increase in the amount of water and fertilizer that percolated through the upper soil layer. The clover acted as a mulch that increased organic matter that, in turn, increased the number of pore spaces in the soil. An increase in water percolation reduced erosion to nondetectable levels. Crop rotations that use forage legumes greatly reduce soil loss. Stewart et al. (1975) showed that the dense vegetative cover and rooting of these crops resulted in a negligible soil loss. The residual mulch improved infiltration, and soil did not erode for several years afterward. Cover crops reduce soil loss by up to $50 \%$ when followed by crops with little residue cover, such as corn silage, some grain legumes, and most vegetable crops (Papendick and Elliot, 1984). Most of the benefits of erosion control come from the residue left on the soil surface or mixed in the soil upper layers. Erosion is also influenced by conservation tillage practices that increase soil surface roughness. Improved infiltration and less water runoff resulted from the above (Hargrove, 1985).

\section{Fertility}

Fertility management is important in sustainable crop production. 
Any reduction in the amount of synthetic nutrients applied, especially $\mathrm{N}$, will reduce production cost and environmental contamination. Kelly (1990) discussed the limitations of other sources of N, i.e., meat biproducts and manures, and pointed out the availability of voluminous literature on the benefits of organic matter and the fixation of $\mathrm{N}$ by legumes; he mentioned that more research is not needed. He has appropriately noted the need for improved management, crop rotation with legumes, erosion control, and splitting applications of $\mathrm{N}$. In the southeastern United States, with $<1 \%$ organic matter in the soil, these practices are especially important. In addition to $\mathrm{N}$, split applications of other nutrients to minimize leaching is essential on low organic matter soils.

Cover crops are used frequently in organic systems to provide interim soil cover. They can be planted in the fall or winter when the main crops are not grown, or sometimes interplanted with the main crop. The cover crop is either grazed or returned to the soil as green manure (Papendick and Elliot, 1984; Power, 1987). Rye (Secalecereale L.), wheat (Triticum aestivu $\mathrm{mL}$.), clover (Trifoliu $m \mathrm{sp}$.), vetch (Vicia sp.), and Austrian winter pea (Pisum sativu $m \mathrm{~L}$.) are cover crops best suited for humid areas of the United States (Pieters,1927), like the upper Midwest and Southeast or those areas under irrigation. These cover crops are less suitable for dry areas because they consume water needed by the following main crop.

The history of growing crops is filled with examples of yield enhancements of nonleguminous crops by incorporating a legume into the preceding growing season (Harrison, 1913; Pieters, 1927; Smith et al. 1987). It was a management practice of $\mathrm{N}$ replacement until the arrival of economical commercial fertilizers. The contribution of symbiotically fixed $\mathrm{N}$ by legumes in crop rotations and the possibilities of meeting crop $\mathrm{N}$ needs by this practice are being reexamined by researchers. The energy crisis of the late 1970s raised the question of the wisdom of depending on fertilizer $\mathrm{N}$ as the primary source of $\mathrm{N}$ input into crop production systems (Power, 1987).

Pieters (1927) states that many crops have been used for cover crops but the choice ultimately depends on climatic conditions, the cropping system practiced, and the availability of seed. Researchers in the Southeast have found legumes such as crimson clover, subterranean clover (T. subterraneu and hybrid vetch (Vicia sativa )add 90 to $135 \mathrm{~kg}$ fertilizer N/ha to the soil. Utomo et al. (1985) and Frye and Blevins (1989) found that hairy vetch resulted in the greatest yields of corn grain because it produced more dry matter, thus more mulch, and higher $\mathrm{N}$ content $\left(135 \mathrm{~kg} \cdot \mathrm{ha}^{-1}\right)$ than other cover crops.

\section{Pest management}

Weeds, diseases, nematodes, and insects cause substantial quality and yield losses in vegetable production. Pesticides registered for use in vegetable production are limited. Some registered pesticides are withdrawn from the market every year. Also, there is a major consumer concern about pesticide residues in fresh produce as well as in the environment.

Weeds. Biological, cultural, and mechanical techniques for minimal herbicide inputs have been outlined (Parish, 1990; Phatak, 1987b; Putnam, 1990). Others at this colloquium indicate that a promising cultural approach-use of cover crops for weed management, soil improvement and soil conservation-is gaining acceptance by researchers and vegetable growers. Phatak (1987a, 1987b) and Putnam (1990) proposed that with proper management, cover crops could suppress most weeds by smothering or allelopathy. Smother crops are widely used to reduce weed populations. Cereal grains, buckwheat (Fagopyrum esculent mMoench), and sorghum-sudan hybrids are examples of effective smother crops (Putnam, 1990; Weston et al., 1989). They are quickly established and proceed to use up the resources that weeds would otherwise use. Many are believed to suppress weeds through both competition and allelopathy (Overland, 1966). Cover crops that provide a smothering effect and whose residues also provide allelopathic effects on weeds are gaining approval by vegetable growers (Putnam, 1990). Rye is one such commonly used crop. If residues of rye are left on the soil surface, they release chemicals inhibitory to seedling growth of many annual dicotyledonous weeds (Barnes and Putnam, 1983). The response of grassy weeds is more variable. Additional benefits of rye residues are soil and water conservation and protection of seedlings from wind damage. In vegetable production, wind protection is necessary to ensure a good flower and fruit set. Brunson (1991) found rye residues completely shaded out weeds while still allowing full cantaloupe (Cucumis mel oL.) vine development. Putnam (1990) obtained early weed control with rye residues in cucumber (Cucumis sativu sL.) and snap beans. The rye was able to establish a canopy that effectively suppressed the later-emerging weeds. The concept of a "living mulch" has been suggested to manage weeds in vegetable production (Lanini et al., 1989). Living mulches are plants grown in place, which suppress weeds by blocking light. Unlike other conventional mulches, living mulches are rooted and do not blow away. They may also improve organic matter content. To avoid plant competition, living mulches are usually chemically suppressed before crop planting. Our research in the Southeast has shown that some coolseason cover crops gradually die out during crop growth and do not compete for water or nutrients. However, in our multidisciplinary research some cover crops that remain active during spring-summer, e.g., subterranean clovers (T. suterraneau $m \mathrm{~L}$.), red clover (T. pratense L.), etc., compete with vegetable crops. Weeds were suppressed early due to competition by the covers for light, water, and nutrients. Mustards showed some allelopathic properties against weeds and crops. Various overwintering cover crops provide acceptable weed control for relay-cropped cucumbers (Phatak et al., 1991). However, in general these cover crops are managed in a minimum-till approach where cover crops are destroyed by disking or killed with broadspectrum herbicides (e.g., paraquat, glyphosate, etc.). Destruction of these cover crops also destroys the habitat for beneficial insects and other beneficial organisms. In our studies with cover crops conducted during last 4 years, 13 different beneficial insects were observed (Brunson, 1991; Brunson and Phatak, 1990; Bugg et al., 1991). Stripkilling cover crops maintained the habitat for these beneficials; and cucumbers, peppers (Capsicum апnии $m \mathrm{~L}$.) and cantaloupeswere raised without application of any insecticides. Thus, it is essential to develop a multidisciplinary approach if we want to derive maximum benefits from any crop production strategies. Growers are generally confused by the contradictory recommendations received from the specialists.

Diseases. Soil-borne pathogenic fungi and nematodes are limiting factors in the production of vegetables in the southern United States (Sumner et al., 1983, 1986a, 1986b, 1988). Rhizoctonia solan $i$ Kühn, Pythium myriotylu $m$ Drechs., $P$. aphanidermatu $m$ (Edison) Fitzp., and $P$. irregulur $e$ Buis. are the most virulent pathogenic fungi that cause pre- and post-emergence damping-off on cucumber and snap bean. Sclerotium rolfsi Sace. causes root, hypocotyl, and stem rot in cucumber and snap bean. Root-knot (Meloidogyne incognita and other nematodes can cause severe yield losses in vegetables. Infected plants that do not die may be stunted and unthrifty because of 1) lesions caused by fungi on primary or secondary roots, hypocotyls, and stems or 2) nematode galls on roots. Brunson and Phatak (1990) reported yield reduction from diseases in cantaloupe. The influence of various winter cover crops on the natural biological control of Rhizoctonia solan iand subsequent root disease severity had not been investigated, although it had been known that Rhizoctonia - like fungi antagonistic to $R$. solani were common in Georgia Coastal Plain soils (Sumner and Bell, 1982, 1988).

Soil-borne and foliar pathogens cause substantial quality and yield losses in vegetables. Traditionally, to minimize the losses caused by incidence of diseases, vegetable growers are advised to bury plant debris with moldboard plow (Phatak, 1987a, 1987b; Sumner et al., 1981, 1986b). Thus, cover crops are buried to reduce diseases, and conservation tillage is rarely practiced. Burying cover-crop residues destroys the habitat for beneficial insects and eliminates soil conservation as well as weed-control benefits. In our multidisciplinary studies, we saw differences in soil-borne organisms following various overwintering cover crops (Phatak et al., 1990, 1991; Sumner et al., 1991). With increased interest in sustainable vegetable production there will be a need to evaluate soil conservation strategies for disease management in vegetables. 
Nematodes. Nematodes also cause substantial losses in vegetable yield. Minton (1986) reported that in conservation tillage, rye cover reduced populations of southern root knot nematodes (Meloidogyne incognita) compared with winter weed cover. In our trials there were no differences among cover crops for any of the pest nematodes studied at planting of cucumber crop. However, the cucumber crop planted following some legumes was severely infested with southern root-knot nematodes (Phatak et al., 1991). Use of cultivars resistant to nematodes (Sasser and Kirby, 1979); rotating with nonhost crops; planting antagonistic plants (e.g., marigold, hairy indigo, showy crotoloria, sunn hemp, velvetbean, castorbean, etc.) that will inhibit or kill nematodes, and application of chitin (CladoSan) may be helpful in nematode-infested areas (Leonard, 1991). Some grasses and crucifers generally do not support nematodes. Root knot-tolerant red clover (Quesenberry et al., 1989), reduced nematode population in our trials. However, it proved to be very vigorous and grew faster than tomatoes (Lycopersicon esculentum Mill.) planted after clipping or application of glyphosate, smothering the tomatoes.

Insects. Soil insects, aphids, and thrips cause substantial crop losses annually. There is little information on the effect of cropping sequences and cover crops on beneficial and pest insect populations. Bugg and Wilson (1989) found that generalist predators may be important in the biological control of insects that attack warm-season vegetable crops. They found that during periods when pests are scarce or absent, several important predators can subsist on nectar, pollen, and alternative prey afforded by cover crops. Altieri and Letourneau (1982), Altieri and Schmidt (1985), and Bugg and Ellis (1988) postulated that this could lead to enhanced biological control on the beneficiary crops. Bugg et al. (1990) have shown that in south Georgia the insidious flower bug [Orius insidiosus (Say)], bigeyed bugs, (Geocoris spp.), and various lady beetles (Coleoptera: Coccinellidae) can attain high densities in various vetches, clovers, and certain Cruciferae. These predators subsisted and reproduced on nectar, pollen, thrips, and aphids and thus were established before the arrival of key pests (Bugg et al., 1987; Ehler and Miller, 1978; Murdoch et al., 1985; Tamaki, 1981; Tedders, 1983). Bugg et al. $(1990,1991)$ found that when summer vegetables were planted amid "dying mulches" of cool-season cover crops, some insects moved onto the vegetables. To optimize the consequences of such movement, we are conducting research on matching cover crops with the associated vegetable crops. Cover crops selected were those that harbored high levels of beneficial insects. In our multidisciplinary research, cucumbers, cantaloupes, and peppers were grown without the use of insecticides. Providing habitat for beneficial insects and using trap crops will play a major role in sustainable vegetable production.

\section{Conclusions}

Cover crops, living and dying mulches, relay cropping, companion cropping, crop rotations, green manuring, composting, etc. are essential components of sustainable agriculture. Our multidisciplinary research in southeastern United States using winter cover crops in vegetable production is just the beginning. Our research indicated that cover crops offer excellent potential in integrated pest management of weeds, insects, diseases, and nematodes in vegetable production in the Southeast. However, long-term multidisciplinary research to incorporate all essential elements of sustainable vegetable production is needed.

\section{Literature Cited}

Altieri, M.A. and D.K. Letourneau. 1982. Vegetation management and biological control in agroecosystems. Crop Protection 1:405430.

Altieri, M.A. and L.L. Schmidt. 1985. Cover crop manipulation in northern California orchards and vineyards: Effects on arthropod communities. Biol. Agr. \& Hort. 3:1-24.

Barnes, J.P. and A.R. Putnam. 1983. Rye residues contribute weed suppression in no-till cropping systems. J. Chem. Ecol. 19:10451057.

Brunson, K.E. 1991. Winter cover crops in the integrated pest man- agement of sustainable cantaloupe production. MS Thesis, Univ. of Georgia, Athens.

Brunson, K.E. and S.C. Phatak. 1990. Winter cover crops in low-input vegetable production. HortScience 25:1158.

Bugg, R.L., L.E. Ehler, and L.T. Wilson. 1987. Effect of common knotweed (Polygonum aviculare) on abundance and efficiency of insect predators of crop pests. Hilgardia 55(7):1-52.

Bugg, R.L. and R.T. Ellis. 1988. Use of green manure crops to subsidize beneficial insects: a study in progress, p. 553-557. In: P. Allen and D. Van Dusen (eds.). Global perspectives on agroecology and sustainable agriculture systems. Proc. 6th Intl. Conf. Intl. Federation of Organic Agr. Movements (1986) vol. II. Agroecology Program, Univ. of California, Santa Cruz.

Bugg, R.L., S.C. Phatak, and J.D. Dutcher. 1990. Insects associated with cool-season cover crops in southern Georgia: implications for biological control in truck-farm and pecan agroecosystems. Biol. Agr. \& Hort. 7:17-45.

Bugg, R.L. and L.T. Wilson. 1989. Ammi visnaga (L.) Lamarck (Apiaceae): Associated beneficial insects and implications for biological control with emphasis on the bell-pepper ecosystem. Biol. Agr. \& Hort. 6:241-268.

Bugg, R.L., F.L. Wackers, K.E. Brunson, S.C. Phatak, and J.D. Dutcher. 1990. Tarnished plant bug, Lygus lineolaris (Palisot de Beauvois) (Hemiptera: Miridae), on selected cool-season leguminous cover crops: abundance, survival and preference. J. Entomol. Sci. 25:463-474.

Bugg, R.L., F.L. Wackers, K.E. Brunson, J.D. Dutcher and S.C. Phatak. 1991. Cool-season cover crops relayed intercropped with cantaloupe: influence on a generalist predator, Geocoris punctipes (Hemiptera:Lygaeidae). J. Econ. Entomol. 84:408-416.

Ehler, L.E. and J.C. Miller. 1978. Biological control in temporary agroecosystems. Entomophaga 23:207-212.

Frye, W.W. and R.L. Blevins. 1989. Economically sustainable crop production with legume cover crops and conservation tillage. J. Soil and Water Conservation 44:57-60.

Hargrove, W.L. 1985. Legume cover crops in no-till soybeans, p. 2428. In: W.L. Hargrove, F.C. Boswell, and G.W. Langsdale (eds.). Proc. 1985 Southern Region No-Till Conf. Georgia Agr. Expt. Sta., Athens.

Hargrove, W.L. 1986. Winter legumes as a nitrogen source for no-till grain sorghum. Agron. J. 78:70-74.

Harrison, F. 1913. Roman farm management. MacMillan Co., New York.

Howard, A. 1940. 1940. An agricultural testament. Oxford Univ. Press, London.

Kelly, W.C. 1990. Minimal use of fertilizers in vegetable production. HortScience 25:168-169.

King, F.H. 1927. Farmers forty centuries. J. Cape, London.

Lanini, W.T., D.R. Pittenger, W.L. Graves, F. Munoz, and H.S. Agamalien. 1989. Subclovers as living mulches for managing weeds in vegetables. California Agr. 43:25-27.

Leonard, D. 1991. Nematodes. Horticulture. LXIX(3):66-73.

Lowrance, R., B. Stinner, and G. House. 1984. Introduction, p. 1-4. In: R. Lowrance, B. Stinner, and G. House (eds.). Agricultural ecosystems: unifying concepts. Wiley, New York.

MacRae, R.J., S.B. Hill, and G.R. Mehuys. 1989. Agricultural science and sustainable agriculture: a review of the existing scientific barriers to sustainable food production and potential solutions. Biol. Agr. Hort. 6:173-219.

Minton, N.A. 1986. Impact of conservation tillage on nematode populations. J. Nematol. 18:135-140.

Murdoch, W.W., J. Chesson, and P.L. Chesson. 1985. Biological control in theory and practice. Amer. Nat. 125:344-366.

Odum, E.P. 1984. Properties of agroecosystems, p. 5-12. In: R. Lowrance, B. Stinner, and G. House (eds.). Agricultural ecosystems: unifying concepts. Wiley, New York.

Oelhaf, R.C. 1978. Organic agriculture: economic and ecological comparisons with conventional methods. Halsted Press, New York.

Overland, L. 1966. The role of allelopathic substances in the "smother crop" barley. Amer. J. Bot. 53:423-427.

Papendick, R.I. and L.F. Elliot. 1984. Tillage and cropping systems for erosion control and efficient nutrient utilization, p.69-81. In: D.F Bezdicek and L.F. Elliot (eds.). Organic farming. Amer. Soc. 
Agron. Spec. Publ. no. 46.

Parish, S. 1990. A review of non-chemical weed control techniques. Biol. Agr. and Hort. 7:117-137.

Phatak, S.C. 1987a. Tillage and fertility management in vegetables. Amer. Veg. Grower. 35(2):8-9.

Phatak, S.C. 1987b. Integrating methods for cost effective weed control. Proc. Integrated Weed Mgmt. Symp; Expert Committee on Weeds, Western Canada, Victoria, B.C. p. 24-25.

Phatak, S.C., R.L. Bugg, D.R. Sumner, J.D. Gay, K.E. Brunson, and R.B. Chalfant. 1990. Cover crops in IPM of weeds diseases, and insects of vegetables. 23rd Intl. Hort. Congr., Florence, Italy. (Abstr. 3239.)

Phatak, S.C., R.L. Bugg, D.R. Sumner, J.D. Gay, K.E. Brunson, and R.B. Chalfant. 1991. Cover crops effects on weeds diseases, and insects of vegetables. Proc. Int. Conf. Cover Crops for Clean Water, 9-11 Apr. 1991. p. 153-154.

Pieters, A.J. 1927. Green manuring: principles and practices. Wiley, London.

Power, J.F. 1987. Legumes: their potential role in agricultural production. Amer. J. Alternative Agr. 2:69-73.

Putnam, A.R. 1990. Vegetable weed control with minimal herbicide inputs. HortScience 25:165-169.

Quesenberry, K.H., D.D. Baltensperger, R.A. Dunn, C.J. Wilcox and S.R. Hardy. 1989. Selection for tolerance to root-knot nematodes in red clover. Crop Sci. 29:62-65.

Sasser, J. N. and M. F. Kirby. 1979. Crop cultivars resistant to rootknot nematodes, Meloidogyne species with information seed sources. Intl. Meloidogyne Proj. N.C. State Univ. and USAID, Raleigh, N.C.

Smith, M.S., W.W. Frye, and J.J. Varco. 1987. Legume winter cover crops. Adv. Soil Sci.: 7:95-139.

Stewart, B.A., D.A. Woohiser, W.H. Wischmeier, J.H. Caro, and M.H. Frere. 1975. Control of water pollution from cropland. vol.I. U.S. Dept. Agr. and Environ. Protection Agency

Sumner, D.R., B. Doupik, Jr., and M.G. Boosalis. 1981. Effects of reduced tillage and multiple cropping on plant diseases. Annu. Rev. Phytopathol. 19:167-187.

Sumner, D.R. and D.K. Bell. 1982. Root diseases of corn inducted by
Rhizoctonia solani and Rhizoctonia zeae. Phytopathology 72:8691.

Sumner, D.R., C.C. Dowler, A.W. Johnson, N.C. Glaze, S.C. Phatak, R.B. Chalfant, and J.E. Epperson. 1983. Root diseases of cucumber in irrigated, multiple-cropping systems with pest management. Plant Dis. 67:1071-1075.

Sumner, D.R., S.C. Phatak, J.D. Gay, R.B. Chalfant, K.E. Brunson, and R.L. Bugg. 1991. Soilborne pathogens in vegetables with winter cover crops and conservation tillage. Phytopathology $81: 1164$.

Sumner, D.R., D.A. Smittle, E.D. Threadgill, A.W. Johnson, and R.B. Chalfant. 1986a. Interactions of tillage and soil fertility with root diseases in snap bean and lima bean in irrigated multiple-cropping systems. Plant Dis. 70:730-735.

Sumner, D.R., E.D. Threadgill, D.A. Smittle, S.C. Phatak, and A.W. Johnson. 1986b. Conservation tillage and vegetable diseases. Plant Dis. 70:906-911.

Sumner, D.R., S.R. Ghate, and S.C. Phatak. 1988. Seedling diseases of vegetable sin conservation tillage with soil fungicides and fluid drilling. Plant Dis. 72:317-320.

Tamaki, G. 1981. Biological control of potato pests, p. 178-192. In: J.H. Lashomb and R. Casagrande (eds.). Advances in potato pest management Hutchinson Ross, Stroudsberg, Pa.

Tedders, W.L. 1983. Insect management in deciduous orchard ecosystems: Habitat manipulation. Envir. Mgmt. 7:29-34.

Utomo, M., W.W. Frye, and R.L. Blevins. 1985. Functions of legume cover crops in no-till and conventional till corn production, p. 6368. In: W.L. Hargrove, F.C. Boswell, and G.W. Langsdale (eds.). Proc. 1985 Southern Region No-Till Conf. Georgia Agr. Expt. Sta., Athens.

U.S. Department of Agriculture. 1980. Report and recommendations on organic farming. Superintendent of Documents, Washington, D.C.

Weston, L.A., R. Harmon, and S. Mueller. 1989. Allelopathic potential of sorghum-sudangrass hybrid (Sudex). J. Chem. Ecol. 15(6):18551865 . 